\title{
The Impact of Tectonic Setting on Distribution of Kolosh Formation during Paleocene -Lower Eocene in Northern Iraq
}

\author{
Rabeea K. Znad \\ Geology Department \\ College of Science \\ Mosul University
}

\author{
Ibrahim S. Ibrahim Aljumaily \\ Geology Department \\ College of Science \\ Mosul University
}

(Received 28/10/2018 , Accepted 25/6/2019)

\begin{abstract}
This study covered most of Kolosh Formation exposure areas in northern Iraq. Description of the lithology and measuring the actual thickness of the Formation from exposures and well logs were performed. The isopach map of the Formation was constructed. The sedimentation of the Formation was affected by the tectonic activity of the northeastern edge of the Arabian plate during the closure of the Neo-Tethys Ocean. The tectonic setting outlined the depozone of foreland basin system and controlled the variation of the deposits of the Kolosh Formation along the orogenic front (It revealed that there are more than one basin of deposition). The deviations of the depocenters of the Kolosh deposit basins from the current folds are depicted. The counterclockwise rotation of Arabian plate and its oblique collision with Iranian plate as well as the rejuvenation of the basement faults during the peak of the orogeny might cause such deviation.
\end{abstract}

Keyword: Kolosh formation-foredeep - backbulge- depozone-depocenters.

$$
\text { تأثير الوضع التكتوني على توزيع رواسب تكوين كولوش خلال الباليوسين - الايوسين الأسفل شمالي }
$$

تأثر توزيع رواسب تكوين كولوش الفتاني بالنشاط التكتوني للحافة الثمالية الثرقية للطبق العربي أثناء

مراحل إنغلاق محيط التيشس الجديد ونشوء حوض فورلاند زاكروس في جزئه العراقي. تم تفسير انتشار رواسب

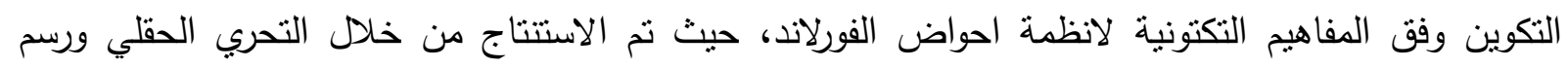

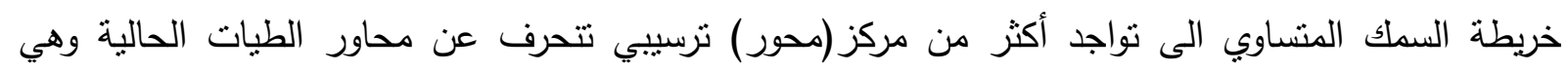

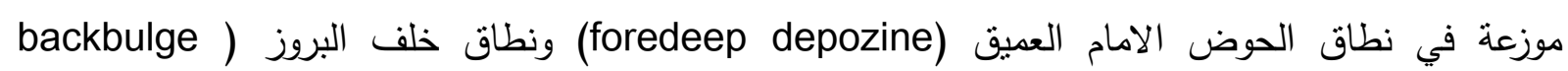
.(depozone الكلمات الدالة: تكوين كولوش، حوض الفور لاند، الحوض الامام، خلف البروز، ز اكروس. 


\section{INTRODUCTION}

Kolosh Formation is one of the widely distributed clastic sediments throughout northern Iraq. Many researchers considered the Formation as flysch deposits due to its lithological characteristics. Thus, the distribution of these deposits reflects the dynamic tectonic setting of Arabian northeastern edge during its subduction under Iranian plate and initiation of foreland basin system during late Cretaceous. The control of this tectonic setting on the distribution of the foreland basin deposits continued throughout early Tertiary. Kolosh Formation represents the clastic unit of fore-deep depozone (Znad, 2013). The constructed isopach map of the Formation depends on detailed fieldwork notes and measure of true thickness on all accessible outcrops, besides well logs. The southwestern rim of Kolosh basin is outlined at its transitional zone with Aliji Formation. The study area comprises most of northern Iraq (Fig. 1).

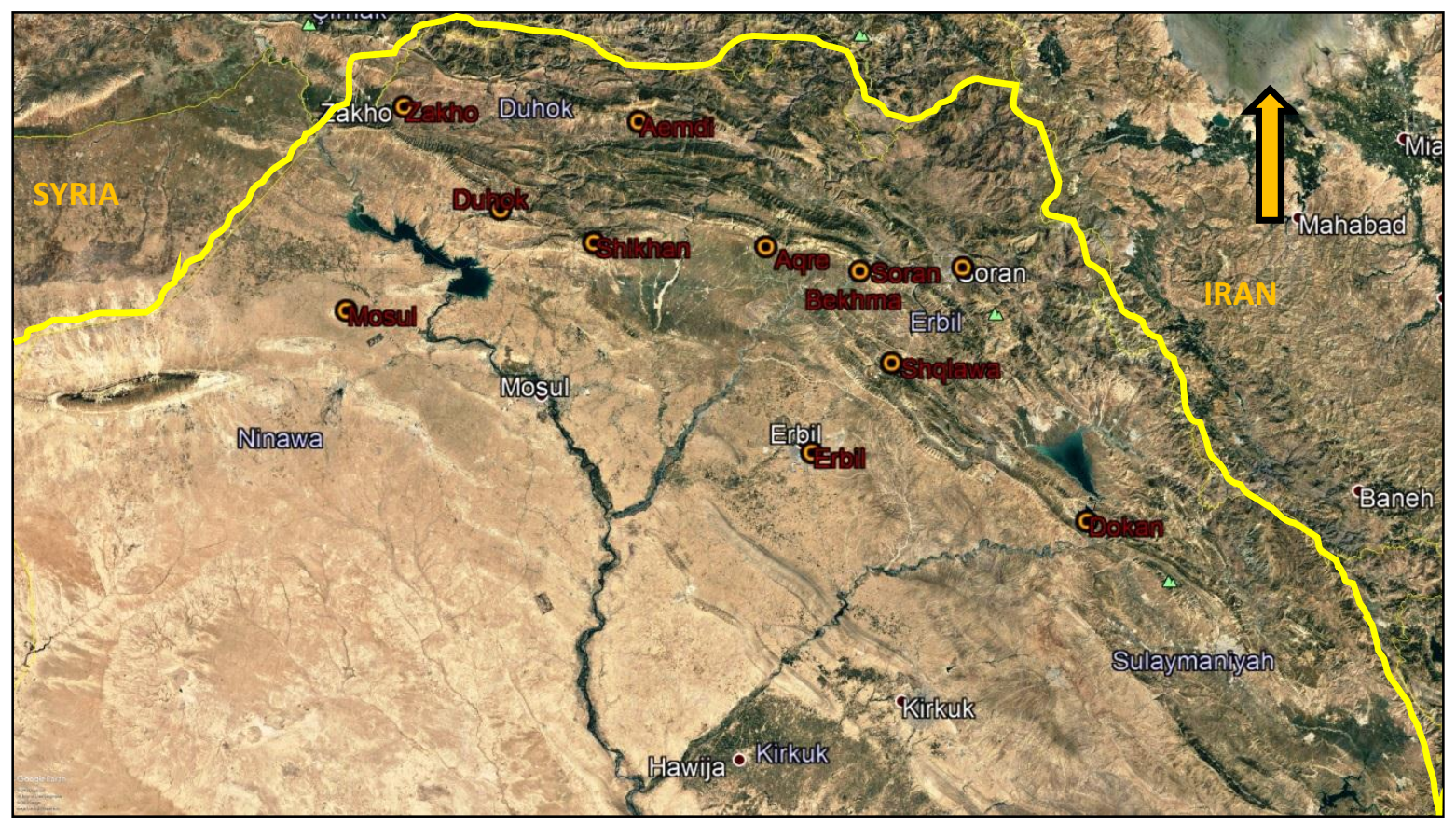

Fig. 1: Northern Iraq showing investigation areas

\section{LITHOLOGY OF KOLOSH FORMATION}

Kolosh Formation type section is cited and described by Dunnington (1952 in Bellen et al., 1959) in Koya within high fold zone of northern Iraq. Its age extends from Paleocene to early Eocene, with 777 meter thickness. The formation consists of rhythmic alternation of thin sandstone, siltstone, marlstone, and less common conglomerate and limestone with calcareous silt shale inter-layers. They resemble flysch-like sediments (Dunnington, 1958).

The Formation crops out on the most areas of northern Iraq without essential differences in lithological nature. Generally, the formation consists of dark grey easily drifted sandstone, shale and claystone (Fig. 2), making wet dark grey soil in the lowland. Sandstone beds range between $(0.25 \mathrm{~m}-3 \mathrm{~m})$ in thickness, of medium hardness and fine grained in general, occasionally pebbly (not more than $2-3 \mathrm{~cm}$ ). Conglomerate beds have thicknesses of about (1-2 m) with pebbles (not more than $4 \mathrm{~cm}$ in size). The 
pebbles are mainly limestone and chert, spherical in shape, sorted and rounded. They are poorly cemented with sandy and clayey materials, and occasionally bituminous.

In Shaqlawa area, there is an increase in dark shale upward the section, with bituminous saturated sandstone beds and abundance of trace fossils and sedimentary structures (Fig. 3).

\begin{tabular}{|c|c|c|c|c|}
\hline Description & Lithology & $\begin{array}{c}\text { Thick } \\
\text { (m) }\end{array}$ & $\mathrm{Fm}$ & Age \\
\hline $\begin{array}{l}\text { Light grey succession of thin layers; sandstone, } \\
\text { marl and marly limestone. } \\
\text { Dark grey succession of; sandstone, marl, clay } \\
\text { and dark shale. } \\
\text { Friable, wetted sometimes, (fine to coarse grain) } \\
\text { Sedimentary structures, bituminous matter. }\end{array}$ & 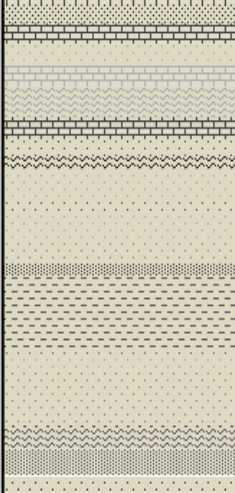 & $\begin{array}{l}8 \\
\frac{8}{1} \\
8\end{array}$ & 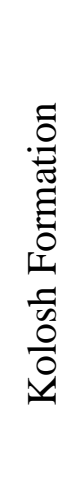 & 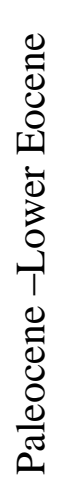 \\
\hline
\end{tabular}

Fig. 2: Lithology of Kolosh Formation in Bekhme area.
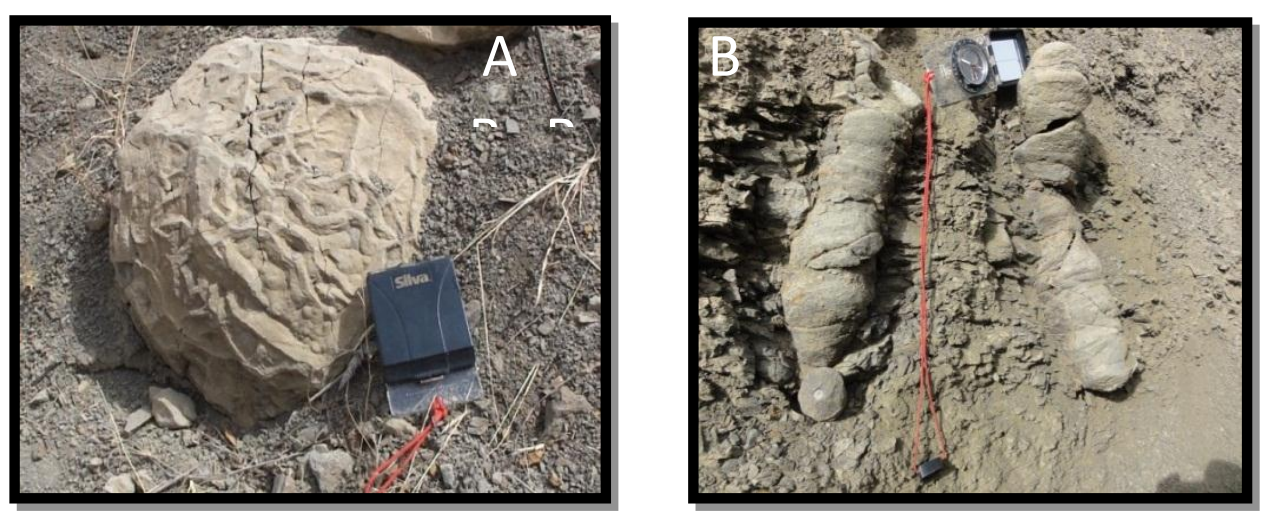

Fig. 3: Trace fossils in Kolosh Fm. Shaqlawa Area.

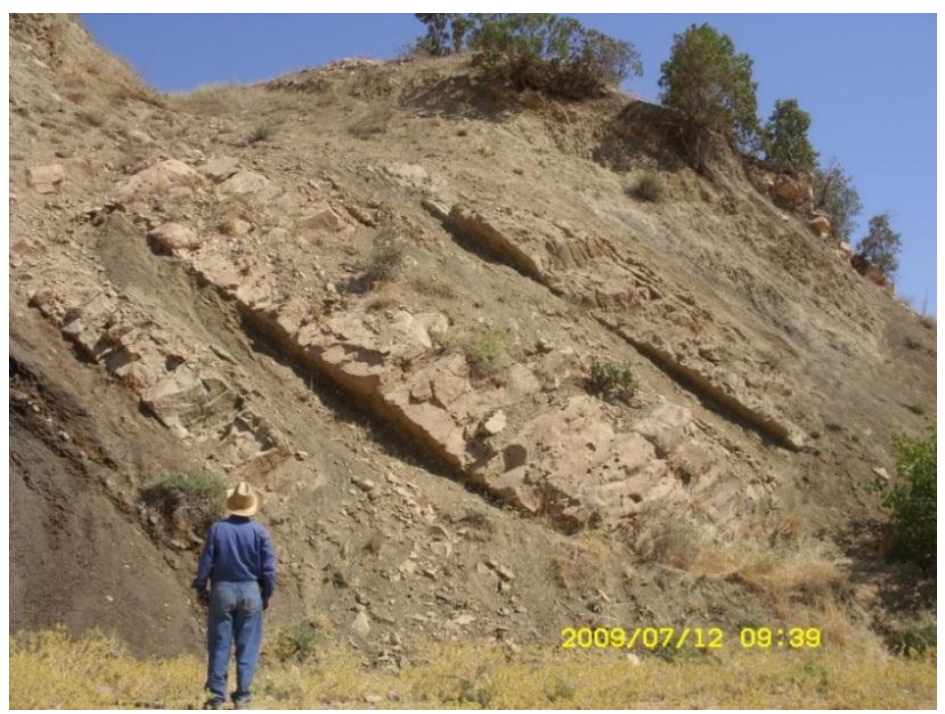

Fig. 4: Field photo illustrating the gradually altering of Kolosh Formation to Khurmala Formation in Bekhair anticline. 
In Bekhair anticline, the ratio of thin limestone beds increases upward the section and alters gradually to dolomitic limestone of Khurmala Formation (Fig. 4).

In the Shiranish Islam area, there is an increase in the proportion of sandstone on expense of claystone beds and absence of limestone beds. The presence of trace fossils and Gastropoda molds were noted as well (Fig. 5).
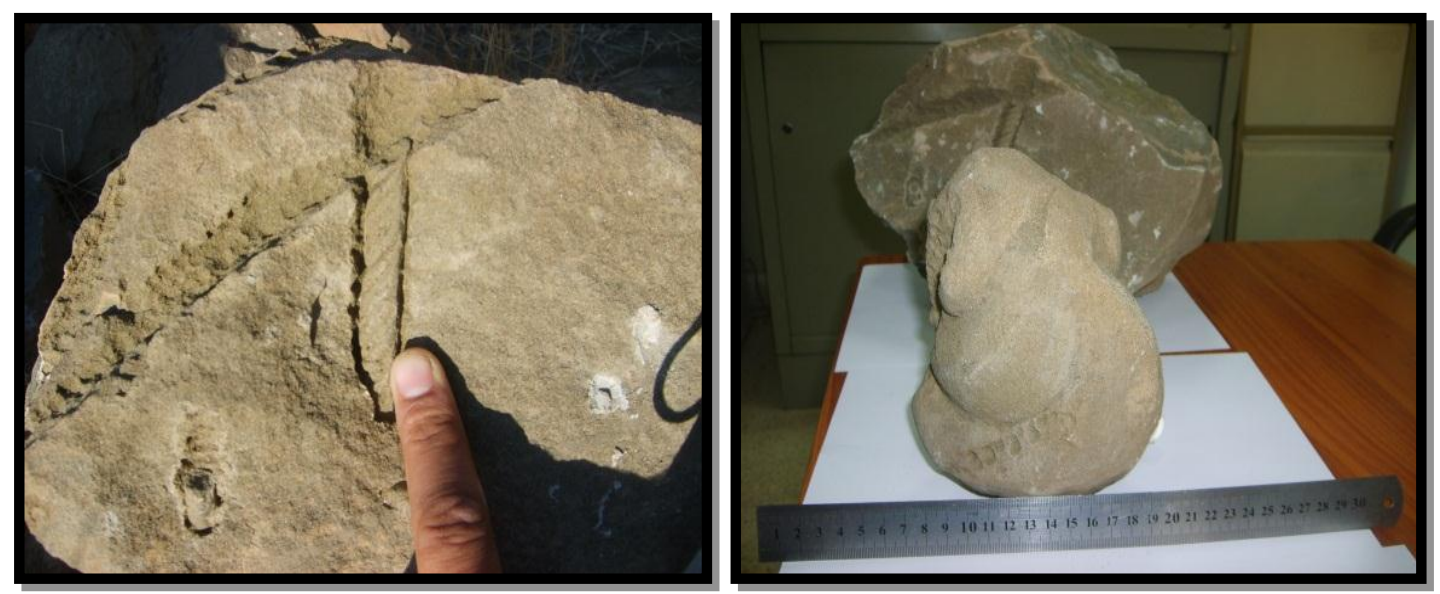

Fig. 5: Trace fossils and Gastropoda molds from Kolosh Formation in Shiranish Islam area at Zakho district

The upper and lower boundaries of Kolosh Formation are varying geographically from one area to another of the study area. That is due to tectonic setting variance of the Formation depositional basin.

In Perat fold at Bekhme region, the formation overlies uncomfortably the Tanjero Formation (Late Cretaceous). The contact between them is identified there through color change from olive green rocks of Tanjero Formation to dark gray rocks of Kolosh Formation. Further, it is assured by fossil investigation.

In Safine anticline (Shaqlawa area), Bekhair anticline (Dohuk area) and in Shiranish Islam village (Zakho area), the lower contact of Kolosh Formation is not compatible with the Shiranish Formation. The contact is determined there in the field at appearance of first sandstone layer of Kolosh Formation after marl layers of Shiranish Formation.

In Mashura well (northwest of Mosul), the lower boundary of the formation is intercalated with Aliji Formation (Rafo, 1989). In Shaikhan Anticline, its lower contact is unconformable with Bekhme Formation (Al-Humaidi, 2007; Ahmad, 1980).

The upper contact of the formation in Bekhme area is gradational with Khurmala Formation. It is evident by increasing the number and thickness of marly limestone layers in the upper part of Kolosh Formation.

In Safine anticline (Shaqlawa area), the upper seam contact with the Gercus Formation is sometimes represented by a layer of conglomerate (2-3 m thick) near the city. However, sometimes it is intercalated with the Khurmala Formation, which appears in thickness of several meters compared to that in Bekhme area. While AlMutwali (2001) and Al-Qayim and Salman (1986) considered this intercalation as conformable between the two formations. In the Bekhair anticline, the upper contact of the formation is gradational with Khurmala Formation in certain sites, and there is a pinkish conglomeratic bed (not more $1.5 \mathrm{~m}$ thick). In other sites, the formation 
contacts upward with Gercus Formation. In the Shiranish (Zakho Area), its contact with Gercus Formation is bounded with first appearance of red pinkish sandstone.

According to Al-Humaidi (2007) and Ahmad (1980), the upper contact of the formation is unconformable with the Gercus Formation in Shaikhan anticline.

Most sedimentological criteria reflect that turbidite deposits of Kolosh Formation are due to rapid subsiding tectonic basin (flysch-like origin) (Al-Mashaykh, 1979; Al-Qayim and Salman, 1986; Al-Juboury, 2006; Al-Sakry, 2006; Al-Humaidi, 2007; Al-Qayim et al., 2008).

\section{ISOPACH MAP OF KOLOSH FORMATION}

Isopach maps are valuable to define the tectonic framework or the structural relationships accountable for accumulation of a specific type of sediments. These include delineating basin shape, coastal line location and rising areas. However, to some extent and under certain circumstances, thickness variance maps with specific stratigraphic disjunctives are useful in estimating vertical uplift and erosion (Krumbein and Sloss, 1963). Practically, thickness maps are also valuable to explicate major depositional centers locations and borders, and as well depositional synchronous subsurface structural relieves where sediments become thinner and shallower (Miall, 1999). Also, the spread of detrital deposits reflects the dynamic of depositional basin because it is related to the sediment source and the transport mechanism. Detailed surface observations and field data were mainly based on the mapping, as well as some subsurface data were obtained from the records of exploratory wells and other sources listed in Appendix 1. The map is drawn using Surfer 6 software package.

In the beginning, the distribution of Kolosh Formation can be clarified according to the foreland basin system (Fig.6). The formation occupies the foredeep depozone basin in Rawanduz area and extends towards Suran and Barzan. The extension of the fore-deep depozone basin in southeast Turkey is occupied with Kolosh-like sediments known as Kermave Formation. The spread of Kolosh Formation is variable along the strike of the fore-bulge depozone. The formation is absent on both flanks of Mateen and Gara anticlines and towards Aqra anticline as well, indicating exposure of this zone during the Paleocene.

At Galley Zanta on northern limb of Aqra anticline and closer to its eastern plunge, there exposed a succession of fine-grained sandstones (with cross bedding and iron oxide traces), marl and limestone beds. Malak (2010) included the upper (30) meters of this succession within Kolosh Formation. This succession reflects facies deposited in a shallow marine extending between under-tidal and over-tidal environments. Then the formation continues from there toward southeast to Bekhme gorge (Perat anticline).

The isopach map of Kolosh Formation (Fig. 7) shows that the basin axis of deposition was extending northwest-southeast (the depocenters is located at maximum thickness contours, Selley, 1976). The southwestern boundary of the formation is an overlap with Aliji Formation extending along the Tigris River in Mosul district. It extends southeastward towards Kirkuk. The northeastern border of the formation extends adjacently to thrust zone along the northern limit of Rawanduz district, 
passing through Suran area, to the eastern plunges of Gara and Mateen anticlines, and extends into the southeastern parts of Turkey along the Iraqi borders.

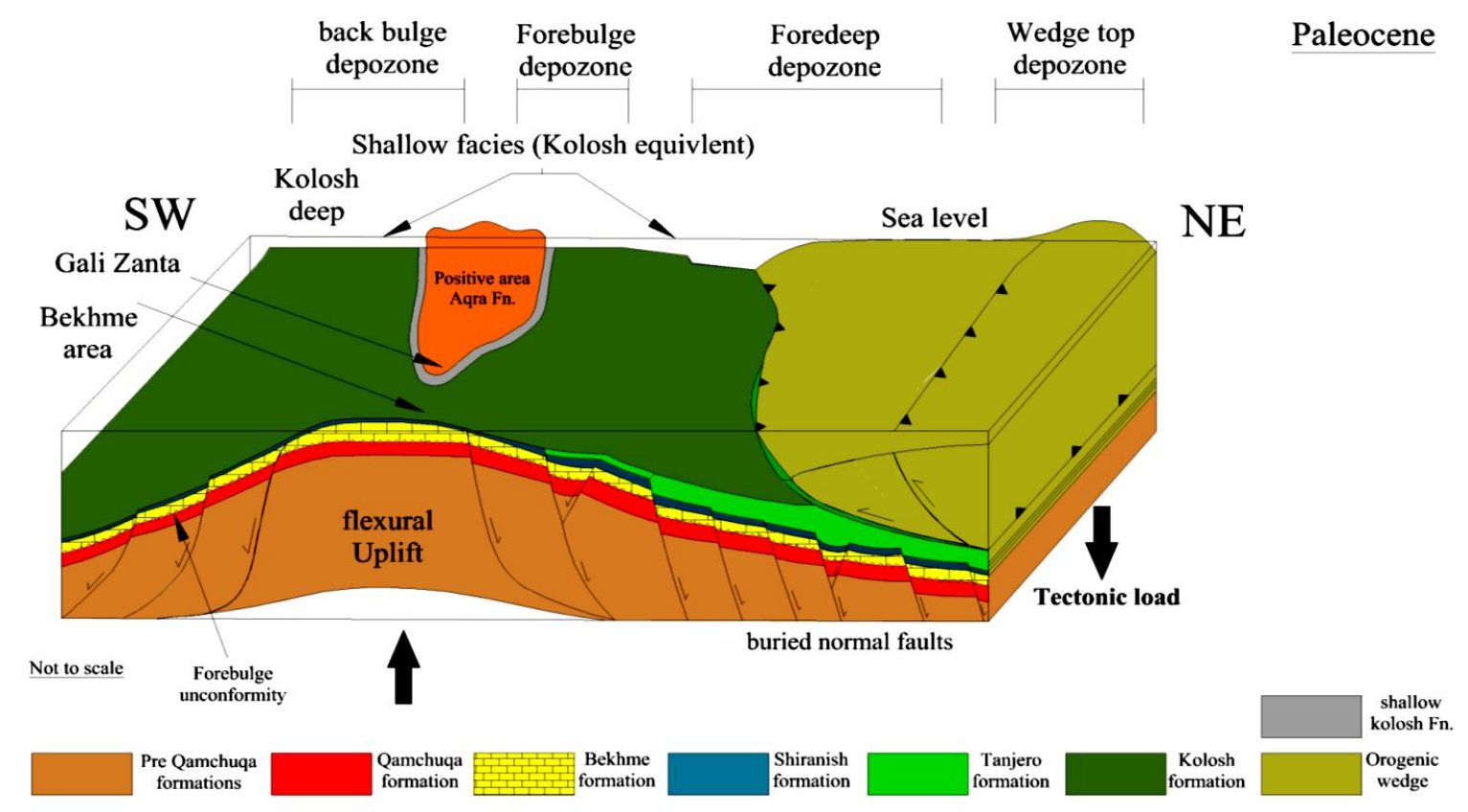

Fig. 6: A perspective illustrating the configuration of the foreland basin system deposition zones during the Paleocene.

Also, the map shows two major and another minor deposition centers in the back-bulge depozone. The first depositional center extends northwestsoutheast at Duhok area, called Duhok-Qand basin. The northeastern boundary of this basin starts from west of Khabour River, through Mateen anticline (Galy Dhe), extending to the south Soura Tuka and Besari, and continues to the Galy Qeer in Shaikhan anticline. This limit outlines first appearance of Kolosh Formation where it is intercalated with Khurmala Formation in many localities.

The second sedimentary center extends northwest-southeast as well and called Shaqlawa basin. It is wider than the first basin and connected with the fore-deep depozone basin across the fore-bulge. This connection can be attributed to the reach of the fore-deep basin to fill stage during deposition of the upper parts of Kolosh Formation and the migration of the sedimentation center to the southwest, as well as the subsidence of the fore-bulge due to the sediment loads.

The minor sedimentation center lies south of Erbil and extends northsouth. It may represent an inherited structural depression that is activated during the deposition of Kolosh Formation, as it corresponds to the location of a back bulge depozone, in which Jawan Formation had been deposited at the beginning of imitation of foreland basin in Kirkuk embayment (Znad, 2013). The isopach map denotes the reduction of Kolosh Formation in the area between the two main basins. This area extends mainly to the west of the Great Zab River. They correspond to the uplifted eastern boundary of Mosul basement block as pointed by Numan (1984). 


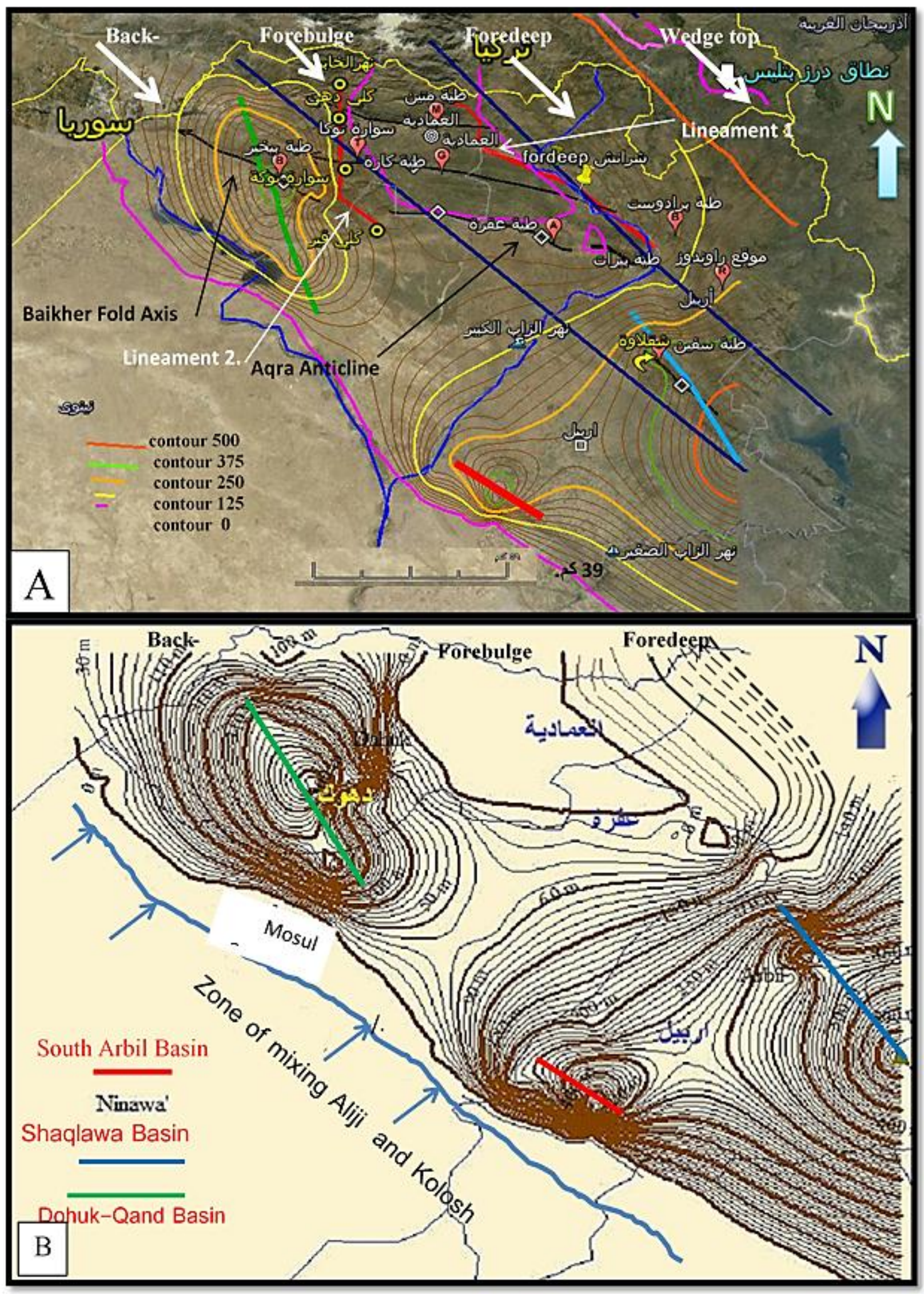

Fig. 7: Isopach map of Kolosh Formation 


\section{TECTONIC IMPLICATIONS OF THE AERIAL DISTRIBUTION OF KOLOSH FORMATION}

It is clear from the distribution of Kolosh Formation in the study area that its sedimentary history is largely related to the closure of the Neo-Tethys Ocean and the subsequent convergence between Arabian and Eurasian plates. The absence of Kolosh Formation on northern and southern limbs of both Mateen and Gara anticlines, and ahead to Aqra anticline, indicates the uplift and exposure of this region during the deposition of Kolosh Formation, where Gercus Formation (Eocene) overlies Aqra Formation in this area with unconformable contact. However, low-up tide shallow marine facies overlies Aqra Formation in the Galley Zanta area toward the eastern plunge of Aqra anticline. Thus, this uplift is considered as the fore-bulge depozone concomitance of the fore-deep depozone that accompanied subduction of Arabian plate under Turkish plate. Noteworthy, there is an extension of Kolosh Formation of fore-deep depozone in southeast Turkey known as Kermave Formation there.

The present study identified some lineaments extending regionally (Fig. 7A, marked in red) which correspond roughly with the general boundaries of the fore-bulge depozone. So, these structures might be related to deep seated inherited or emergent faults during the flexural uplift of the fore-bulge caused by the tectonic load of Turkish plate on the edge of Arabian plate. These lineaments trend north-south in the northern parts of the study area, crossing the eastern and western domains of Mateen and Gara anticlines respectively, and then reorienting to northwest-southeast along with the general extension of the fore-bulge. The first main linear structure extends along with the course of the Great Zab River starting from its entry into Iraqi territory (Fig. 7A). Albarefkani (2008) recognized this structure as strike-slip fault; it is the start of a regional lineation related to Hatra-Bekhme fault separating Kirkuk from Mosul basement blocks (Numan, 1984; 2000).

The second main lineaments represent the northeastern boundary of Duhok-Kand basin (Fig. 7A\&B) extending from west of Khabour River to the western part of the Galy Dhe, and passing through the western part of the Gara anticline (south of Suara Tuka), then close to Galy Besari (eastern plunge of Bekhair anticline), it deviates towards Galy Qeer (Shaikhan anticline), and finally its effect diminishes towards Aqra anticline.

These two main lineaments expanding along with the general trend of the so-called fore-bulge, played an important role in the distribution of Kolosh Formation sediments in Duhok sector, particularly in north-eastern direction (fore-deep depozone) and in the southwestern direction (back bulge depozone) as well.

Another important tectonic implication that can be derived from the isopach map is the axial parallelism of the two main sedimentary basins of Kolosh Formation, as well as their clockwise deviations from the current anticlinal axes. The Dohuk-Qand sedimentary basin axis deviates about $(35)^{\circ}$ from Bekhair anticline axis, and more than $(80)^{\circ}$ from Mateen and Gara folds 
axes. The Shaqlawa basin deposition axis deviates approximately $(15)^{\circ}$ from Safine and Permam folds axes.

These variances of current folds axes from depositional axes of the two main Kolosh Formation basins is attributed to the counterclockwise rotation of Arabian plate during its collision with Eurasian plate; where the axes of generated folds are normal the regional compression direction resulted from this collision, and hence, the current folds axes became oblique to the inferred depocenters of the Kolosh Formation basins.

\section{CONCLUSIONS}

The present study has revealed the spread of Kolosh Formation sediments throughout an isopach map constructed for the formation. Two main and a minor sedimentation basins of the formation are determined. Areas of the formation non deposition in northern Iraq are detected and considered as emerge regions (bulge) during Paleocene-early Eocene. The tectonic activity influence of the Zagros foreland basin on the spread variance of the formation has been elicited. Also, the deflection of the formation depositional axes from current folds axes in the area has been deduced and attributed to a later counter clockwise rotation of Arabia during its collisional episodes.

\section{REFERENCES}

Ahmad, M.A., 1980.Geology of Shaikhan Area, Unpubl. M.Sc. Thesis, University of Mosul, 178p.

Al-Barefkani, M.J.N., 2008. Structural and Tectonic Analysis of the Northern Thrust Zone (East Khabour River) in Iraq, Unpubl. Ph.D. Thesis, Mosul Univ. 214p. (In Arabic).

Al-Hubiti, S.T., 2008. Tectonic Style Changes along Bekhair Anticline Axis Northern Iraq. Unpubl. M.Sc. Thesis, Mosul Univ. 124p. (In Arabic).

Al-Humaidi, R.I., 2007. Facies Analysis and Sedimentary Environment for late Campanian-late Eocene in Shaikhan Anticline -North Iraq. Unpubl. Ph.D. Thesis, Mosul Univ. 151p. (In Arabic).

Al-Mashaykh, S.Z., 1979. Lithological and Sedimentological Study of Kolosh Formation on North east Iraq. Unpubl. M.Sc. Thesis, Baghdad Univ. 233p. (In Arabic).

Al-Juboury, A.I., 2006. Sandstone Composition and Provenance of the PaleoceneLower Eocene Kolosh Formation of North Iraq. Climate \& Biota of the Early Paleogene Conference, Bilbao, Spain, Abstracts Proceeding, pp.5-6.

Al-Mutwali, M.M., 2001. Paleocene-Early Eocene Benthonic Foraminiferal Biostratigraphy and Paleoecology of Kolosh Formation, Shaqlaw Area, Northeast Iraq. Iraqi Jour. of Earth Sci., Vol.1, No.2, pp.12-24.

Al-Qayim, B.A. and Salman, L., 1986 .Lithofacies Analysis of Kolosh Formation, Shaqlawa Area, North Iraq. Jour. Geol. Soc. Iraq, Vol.19, No.3, pp.107-121.

Al-Qayim, B.A., Qadir F.M. and Al-Biaty, F.M., 2008. Dolomitization and Reservoir Characterization of the Cretaceous Qamchuqa Group Khabaz Oil Field, Kirkuk 
Area, Northern Iraq. GEO 2008, Middle East Conference and Exhibition, Manama, Bahrain.

Bellen, V.R.C., Dunnington, H.V., Wetzel, R. and Morton, D.M., 1959. Lexique Stratigraphique International. Fasc.10a, Iraq, Paris, 333p.

Bradley, D.C. and Kidd, W.S.F., 1991. Flexural extension of the upper continental Crust in Collisional Foredeeps. - Geol. Soc. Amer. Bull., Vol.103, pp.1416 1438.

Krumbein, W.C. and Sloss, L.L., 1963.Stratigraphy and Sedimentation. W.H. Freeman $\& \mathrm{Co} ; 2^{\text {nd }}$ Edition, 660p.

Dunnington, H.V., 1958. Generation, migration, accumulation and dissipation of oil in northern Iraq. Habitat of oil: a symposium. A.A.P.G. Tulsa, G.L. weeks (editor), pp.1194-1251.

Numan, N.M.S. and Al-Azzawi N.K., 1993. Structural and Geotectonic Interpretation of Vergence Directions of Anticlines in the Foreland Fold of Iraq. Abhath AlYarmouk ("Pure Science and Engineering", Yarmouk University, Jordan), Vol.2, No.2, pp.57-73.

Numan, N.M.S., 1984. Basement Controls of Stratigraphic Sequences and Structural Patterns in Iraq. Journal of Geological Society of Iraq, Vol.16, pp.8-28.

Numan, N.M.S., 2000. Major Cretaceous Tectonic Events in Iraq. Rafidain Journal of Science, Vol.11, .No.3, pp.32-52.

Malak, Z.A., 2010. Sedimentological and Stratigraphical Study of the Paleocene Eocene Successions from Selected Areas - North Iraq. Unpubl. Ph.D. Thesis, Mosul Univ. 215p. (In Arabic)

Miall, A.D., 1999. Principles of Sedimentary Basin Analysis. Springer -3rd. updated and enlarged edition, 634p.

Rafo, S.S.D., 1989. Planktonic Foraminifera and Biostratigraphy of Aliji Formation in Mashura Well (1), North West Iraq. Unpubl. M.Sc. Thesis, Mosul Univ., 163p. (In Arabic).

Sakry, S.I., 2006. Sequence Stratigraphy of the Paleocene-Lower Eocene Succession, Northern Iraq. Unpubl. Ph.D. Thesis, Baghdad Univ., 225p.

Selley, R.C., 1976. An Introduction to the Sedimentology, Academic Press, New York, 408p.

Znad, R. Kh., 2013. Early Cretaceous - Early Eocene Tectonic Evolution of a Part of Zagros Foreland Basin, Northern Iraq. Unpubl. Ph.D. Thesis, Mosul Univ., 194p. (In Arabic) 


\section{Appendix1}

Data of Isopach map of Kolosh Formation

\begin{tabular}{|c|c|c|c|c|}
\hline longitude & latitude & thickness & Location & Reference \\
\hline 42.42827 & 36.95097 & 138 & Mashura Well & (Rafo, 1989) \\
\hline 42.85233 & 36.76353 & 284 & Khanki Well & Albarefkani (2008) \\
\hline 43.01556 & 36.66945 & 337 & Qand Well & Albarefkani (2008) \\
\hline 43.44721 & 36.50557 & 30 & Maqloob Anticline & \\
\hline 43.97234 & 36.77582 & 30 & Galley Zanta ,north & \\
\hline 43.97321 & 36.73253 & 10 & Galley Zanta.south & \\
\hline 43.30475 & 36.78928 & 62 & Shaikhan Anticline & Ahmed (1980): \\
\hline 43.02267 & 36.87784 & 233 & Bekhair anticline & Al-Hubiti,2008 \\
\hline 43.08784 & 36.90798 & 371 & Bekhair anticline & \\
\hline 43.04008 & 36.91326 & 306 & Bekhair anticline & Al-Hubiti,2008 \\
\hline 43.01592 & 36.93071 & 300 & Bekhair anticline & \\
\hline 42.96801 & 36.9299 & 422 & Bekhair anticline & Al-Hubiti,2008 \\
\hline 42.99524 & 36.90663 & 421 & Bekhair anticline & \\
\hline 42.85871 & 37.22851 & 110 & Shiranish Islam & \\
\hline 43.14964 & 37.16169 & 110 & Gale Dhe & \\
\hline 43.15544 & 37.25208 & 70 & West khabour river & \\
\hline 42.81158 & 37.13719 & 310 & Tawki Well & Al Barefkani (2008) \\
\hline 42.75481 & 37.29148 & 110 & Zakho, kasrook & \\
\hline 43.15689 & 36.82773 & 100 & Berifka Anticline & \\
\hline 43.06354 & 36.90397 & 209 & & \\
\hline 43.09958 & 36.87326 & 120 & & \\
\hline 42.9199 & 36.94749 & 400 & & \\
\hline 42.93959 & 36.96072 & 400 & & \\
\hline 43.21622 & 36.96822 & 50 & West Suara Tuka & \\
\hline 44.03183 & 36.738 & 0 & & \\
\hline 43.69742 & 36.81527 & 15 & East Aqra, Bakerman & \\
\hline 43.37681 & 36.83925 & 30 & & \\
\hline 43.32983 & 36.96461 & 0 & & \\
\hline 43.89012 & 36.76589 & 8 & $\begin{array}{c}\text { Aqra, Galley Abd } \\
\text { Aziz }\end{array}$ & \\
\hline 44.141 & 36.72 & 0 & & \\
\hline 44.206 & 36.685 & 140 & Bea Village & \\
\hline 44.235 & 36.662 & 90 & $\begin{array}{l}\text { Kolosh /Tanjero } \\
\text { Contact }\end{array}$ & \\
\hline 44.281 & 36.706 & 100 & Northern Bekhme & \\
\hline 44.283 & 36.6212 & 144 & Spelik & \\
\hline 44.359 & 36.54 & 185 & Harer & \\
\hline 44.3233 & 36.4125 & 510 & $\begin{array}{l}\text { Kolosh /Gercus, } \\
\text { Shaqlawa }\end{array}$ & \\
\hline 44.3079 & 36.3707 & 310 & $\begin{array}{c}\text { Shiranish/Kolosh } \\
\text { SW Hijran,Shaqlawa }\end{array}$ & \\
\hline
\end{tabular}




\begin{tabular}{|c|c|c|c|c|}
\hline longitude & latitude & thickness & Location & Reference \\
\hline 44.2556 & 36.3561 & 331 & Hijran Section & \\
\hline 44.5779 & 36.1218 & 662 & Bana Bawi Anticline & Sakry,2006: \\
\hline 43.7512 & 36.1961 & 204 & Dmer Dagh & North Oil Company \\
\hline 43.5087 & 36.0433 & 237 & Quer & North Oil Company \\
\hline 44.37 & 36.652 & 110 & $\begin{array}{c}\text { Perat Anticline } \\
\text { plunge }\end{array}$ & \\
\hline 42.31525 & 37.05267 & 0 & & \\
\hline 43.85801 & 36.83029 & 0 & & \\
\hline 43.81037 & 36.82602 & 0 & & \\
\hline 43.75857 & 36.83471 & 0 & & \\
\hline 43.71669 & 36.83047 & 0 & & \\
\hline 43.6896 & 36.83338 & 0 & & \\
\hline 43.64174 & 36.8373 & 0 & & \\
\hline 43.6174 & 36.84574 & 0 & & \\
\hline 43.58286 & 36.84913 & 0 & & \\
\hline 43.53774 & 36.85753 & 0 & & \\
\hline 43.50166 & 36.86001 & 0 & & \\
\hline 43.44938 & 36.86414 & 0 & & \\
\hline 43.40116 & 36.86741 & 0 & & \\
\hline 43.37153 & 36.8825 & 0 & & \\
\hline 43.34724 & 36.8996 & 0 & & \\
\hline 43.33289 & 36.9229 & 0 & & \\
\hline 43.3274 & 36.94433 & 0 & & \\
\hline 43.30408 & 36.98836 & 0 & & \\
\hline 43.29009 & 37.00277 & 0 & & \\
\hline 43.273 & 37.02157 & 0 & & \\
\hline 43.26247 & 37.04255 & 0 & & \\
\hline 43.24297 & 37.06091 & 0 & & \\
\hline 43.22591 & 37.08123 & 0 & & \\
\hline 43.20951 & 37.09998 & 0 & & \\
\hline 43.1947 & 37.1188 & 0 & & \\
\hline 44.52429 & 35.41831 & 0 & & \\
\hline 44.58496 & 35.3918 & 0 & & \\
\hline 43.1871 & 37.13608 & 0 & & \\
\hline 43.18762 & 37.14743 & 0 & & \\
\hline 43.18776 & 37.1573 & 0 & & \\
\hline 43.18242 & 37.16979 & 0 & & \\
\hline 43.17964 & 37.17934 & 0 & & \\
\hline 43.1777 & 37.19075 & 0 & & \\
\hline 42.91667 & 36.15 & 0 & & \\
\hline 42.81635 & 36.4669 & 0 & & \\
\hline 42.30791 & 36.98961 & 0 & & \\
\hline 42.32038 & 36.90754 & 0 & & \\
\hline 42.38141 & 36.85167 & 0 & & \\
\hline & & & & \\
\hline
\end{tabular}




\begin{tabular}{|c|c|c|l|l|}
\hline 42.45147 & 36.79838 & 0 & & \\
\hline 42.50837 & 36.74662 & 0 & & \\
\hline 42.56698 & 36.69645 & 0 & & \\
\hline 42.61983 & 36.6456 & 0 & & \\
\hline 42.70122 & 36.63843 & 0 & & \\
\hline 42.80622 & 36.62388 & 0 & & \\
\hline 42.87756 & 36.59289 & 0 & & \\
\hline 42.9403 & 36.56175 & 0 & & \\
\hline 43.00221 & 36.52568 & 0 & & \\
\hline 43.05333 & 36.44604 & 0 & & \\
\hline 43.14791 & 36.36973 & 0 & & \\
\hline 43.23243 & 36.25507 & 0 & & \\
\hline 43.30059 & 36.16774 & 0 & & \\
\hline 43.35691 & 36.0782 & 0 & & \\
\hline 43.44847 & 36.00137 & 0 & & \\
\hline 43.52567 & 35.94483 & 0 & & \\
\hline 43.61875 & 35.92157 & 0 & & \\
\hline 43.73959 & 35.90403 & 0 & & \\
\hline 43.82987 & 35.83288 & 0 & & \\
\hline 44.18662 & 35.61321 & 0 & & \\
\hline 44.0913 & 35.67658 & 0 & & \\
\hline 44.034 & 35.72882 & 0 & & \\
\hline 44.2908 & 35.56047 & 0 & & \\
\hline 44.41821 & 35.4951 & 0 & & \\
\hline 44.53505 & 35.4204 & 0 & & \\
\hline 44.535 & 35.42104 & 0 & & \\
\hline 43.535 & 37.12381 & 0 & Mateen , Amedi & \\
\hline 43.6035 & 37.12381 & 0 & Gara. Amedi & \\
\hline 43.42809 & 36.8738 & 0 & & \\
\hline 43.42592 & 36.8657 & 0 & South Gara & \\
\hline 43.27576 & 36.1218 & 0 & Mankesh & \\
\hline 43.1751 & 36.971 & 0 & Spendar,Gara & \\
\hline 43.77138 & 36.84572 & 0 & & \\
\hline 43.73789 & 37.0825 & 0 & & \\
\hline 43.77654 & 37.046 & 0 & & \\
\hline 43.81951 & 37.01009 & 0 & & \\
\hline 43.86236 & 36.979 & 0 & & \\
\hline 43.90926 & 36.9495 & 0 & & \\
\hline 43.95377 & 36.9039 & 0 & & \\
\hline 44.00053 & 36.8663 & 0 & & \\
\hline 43.97605 & 36.83854 & 0 & & \\
\hline 43.93125 & 36.83036 & 0 & & \\
\hline 43.89773 & 36.83049 & 0 & & \\
\hline & & & & \\
\hline
\end{tabular}

